\title{
DIFFERENCES OF THE PRIMARY ENERGY CONSUMPTION OF THE COUNTRIES ALL OVER THE WORLD
}

\author{
Judit Tóth ${ }^{1}$ - Róbert Magda ${ }^{2}$ \\ Szent István University, Faculty of Economic and Social Sciences \\ 2100 Gödöllő, Páter Károly utca 1. \\ ${ }^{1}$ Judit.Toth@phd.uni-szie.hu \\ ${ }^{2}$ Magda.Robert@gtk.szie.hu
}

\begin{abstract}
The global energy consumption is continuously growing, because the population of Earth and the standard of living expands day by day. As a result, the emission of greenhouse gases increases further more. The various countries use the different types of fuels in varying amount.In this study we have examined the primary energy consumption of the countries, according to the BP Statistical Review of World Energy June 2016 (BP, 2016), based upon their usage of fuels.The assay resulted in a 7 cluster model. With one exception, each cluster contains a resource, which is used in a much larger amount than in the other clusters. As a result, we may differentiate between an average cluster, and the clusters of countries that use primarily hydropower, nuclear energy, renewable energy, coal, fossil oil, and natural gas. We have examined if there is any connection between the location of a country in a cluster and its HDI, as well as the countries' competitiveness.
\end{abstract}

Keywords: carbon dioxide (CO2) emissions, Human Development Index, Global Competitiveness Index, primary energy consumption, renewable energy. (JEL Code: Q42, Q43, Q35, Q01, P28, P18)

\section{INTRODUCTION}

Presently one of the greatest challenges for human kind is how to solve the substitution of the rapidly declining energy. The need to decrease the addiction to fossil oil and natural gas has existed for several decades. The energy crisis of the 1970's made the world realize that the economies of certain countries extremely depend from others, which export primarily fossil oil and natural gas. After recognizing this situation, several countries took steps to accelerate experiments and researches regarding the substitution of fossil oil. Since 1975, in several countries, experiments were made with the support of the government, among others in the USA at the Forest Products Laboratory, in Cincinnati, Ohio, and also in Canada at the Intergroup Consulting Economists Ltd., in Winnipeg, Manitoba. The problem of solving the substitution of fossil oil remains present in the experimental and research activities. In 2005, in the 125th anniversary edition of Science magazine the editors named 25 questions which established the mainspring of today's experimental and theoretical researches. Among these questions we may find the following: What and when can replace the cheap fossil oil? (KERR and SERVICE 2005). Researches of today are not only justified by minimization of economic dependence but also by the fact that one of the biggest challenges of the 21th century is to find a solution for problems caused by the climate change.

Developing technological solutions increasing energy efficiency is often induced by more efficient production and consumption technological solutions solve environmental problems, as the better we optimise resource usage, the less we have to actually consume of them. Sadly, in many cases, we can observe the Jevons paradox occuring, which says that increasing efficiency necessarily causes the consumption to increase as well (JEVONS, 1866). For example, efficient fuel usage comes with the increase of cars on the roads, and miles travelled (KEMP et al. 1998; YORK, 2006).

One of the major difficulties with the fossil energy carriers is that these substances increase the carbon dioxide quantity of the atmosphere and thus are responsible for global warming. The United Nations Framework Convention on Climate Change (UNFCCC) established the Kyoto Protocol in 1997. This treaty aims to stabilize the greenhouse gas concentration of the atmosphere in order to ease the foreseen effects of global warming (UNITED NATIONS FRAMEWORK CONVENTION ON CLIMATE CHANGE, 2017). One of the shortcomings of the Kyoto Protocol is that it did not offer 
any technological solutions regarding the problem and it only prescribed obligations, among others to regulate emission, for the first world countries up to the end of 2012. Based upon the collected data, it soon became clear that on a global scale the emission of the greenhouse gases, which reside in the atmosphere for a considerable amount of time, continuedto grow steadily.

In the nineteen fifties, Kuznets created his 'Economic Growth and Income Inequality', in which he stated that in society, the inequality of income will initially increase based on national income, but if it approaches a certain baseline, these inequalities begin to diminish (KUZNETS, 1955). Grossman and Krueger's 'Economic Growth and the Environment' (GROSSMANN and KRUEGER 1995) stressed that there's a connection between harmful environmental load, and national income.

In multiple countries of the EU and the OECD the statement that environmental load increases to a certain level of GDP, after which it decreases. This caused many to conclude that growth turns into development at some point. The theory was proven at long-term, with our current economic growth methods, the curve signaling environmental load may begin to increase again. The curve shaped like an upside-down U was determined when describing contamination causing local and short-term costs. Longterm costs divided more in terms of area, like carbon-dioxide emission, quantity often increases with income (SZLÁVIK, 2013).

\section{LITERATURE REVIEW}

\section{The Emission of Carbon Dioxide}

Countries with well developed economies were fairly successful in decreasing the emission of $\mathrm{CO}_{2}$, however, these results are counterbalanced by the emission of developing economies, mostly in Asia. As a result, the net emission of carbon dioxide continues to grow.

\section{Figure $1 \mathrm{CO}_{2}$ emission deriving from fuel burning (Global Energy Statistical Yearbook, 2016)}

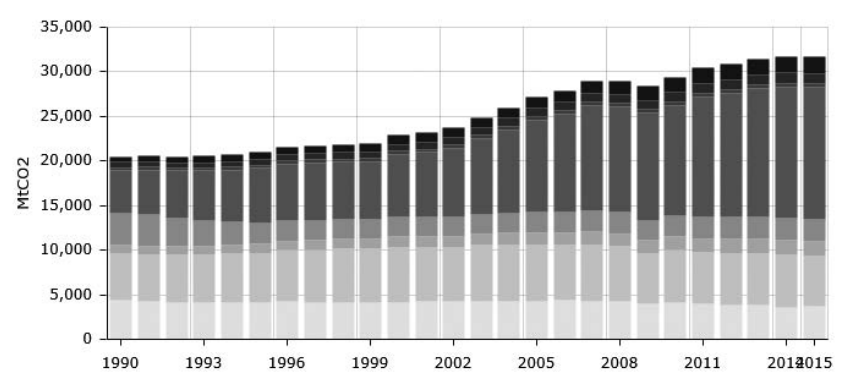

Due to this tendency, the parties of the 1992 Framework Agreement for Climate Change of the UN initiated another reconciliation in 2005 which started a long series of negotiations lasting up to10 years. This resulted in publishing the Paris Agreement. The long term goal of the agreement was to secure that the global warming is kept well under 2 Celsius degrees compared to the rate before industrialization. In addition to this, „we have to aim" that global warming does not exceed 1,5 Celsius degree. We must also aim to stop the increase of global emission „as soon as possible" and after that rapidly decrease global emission in the second half of the 21st century (PARIS AGREEMENT ON CLIMATE CHANGE, 2016). The alternatives of fossil fuels are the renewable energy carriers which help to decrease the emission of gases that are responsible for the greenhouse effect.

\section{Primary Energy Use Today}

Since the key factors - such as the increase of population and living standards -, are influencing energy use globally we may expect a large growth of energy use. It is true in general that if the quality of living increases, the per capita use of energy will increase. In fact, the use of energy can be explained as a combination of three factors: population, per capita GDP and the energy intensity of economy, that is, energy used for one unit of the GDP. According to predictions, until 2040 the absolute rate of energy demand will increase, although the increment percent will decrease.

\section{Research Methodology}

In this study we have examined the primary energy consumption of different countries based on the BP Statistical Review of World Energy June 2016 (BP, 2016), according to their usage of fuels. The comparison of data regarding to certain countries was simplified due to the fact that we did not use the raw data of the tables, but based upon these, we defined the ratio of certain fuels in percentage. Therefore we could eliminate the differences deriving from the size of economy in various countries.

\section{DATA ANALYSIS AND RESULTS}

Examining the sample consisting of 72 units we can see that the economy of an average country uses oil in 38\%, gas in $30 \%$, coal in $16 \%$, nuclear energy in somewhat more than $4 \%$, hydropower in $8,5 \%$ and other renewable energy sources in the remaining $3,5 \%$.

Figure 2 Regional Fuel Usage in 2015(BP, 2016)

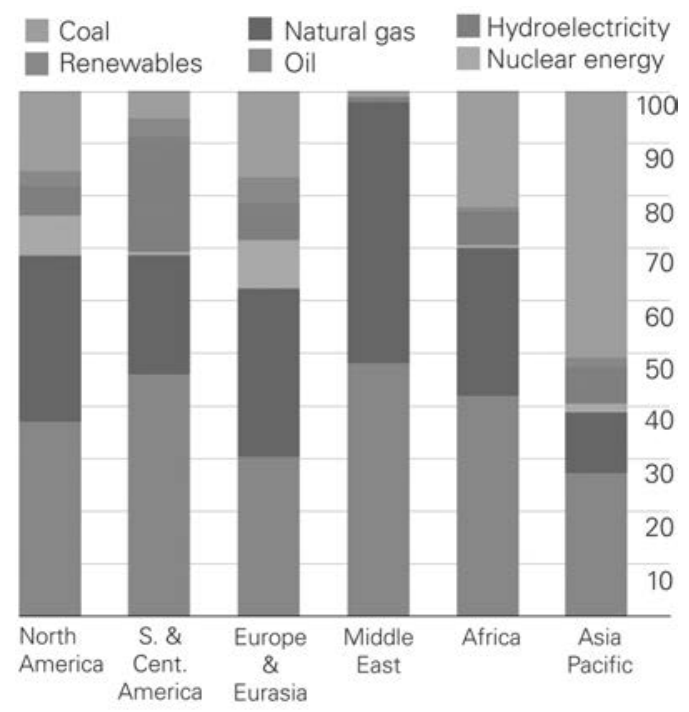


Table 1 Descriptive Statistics, (by the authors,2017)

\begin{tabular}{|c|c|c|c|c|c|c|c|}
\hline & & 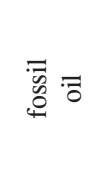 & 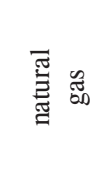 & శ్ & 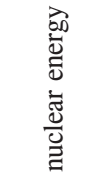 & 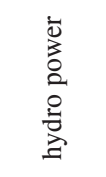 & 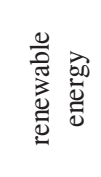 \\
\hline $\mathrm{N}$ & Valid & 72 & 72 & 72 & 72 & 72 & 72 \\
\hline \multicolumn{2}{|c|}{ Mean } & $37,91 \%$ & $29,91 \%$ & $16,06 \%$ & $4,17 \%$ & $8,45 \%$ & $3,50 \%$ \\
\hline \multicolumn{2}{|c|}{ Median } & $36,76 \%$ & $23,80 \%$ & $10,59 \%$ & $0,00 \%$ & $3,63 \%$ & $1,86 \%$ \\
\hline \multicolumn{2}{|c|}{$\begin{array}{l}\text { Std. } \\
\text { Deviation }\end{array}$} & $14,91 \%$ & $21,85 \%$ & $17,00 \%$ & $7,96 \%$ & $11,52 \%$ & $4,58 \%$ \\
\hline \multicolumn{2}{|c|}{ Range } & $81,14 \%$ & $89,93 \%$ & $68,43 \%$ & $41,41 \%$ & $66,08 \%$ & $25,16 \%$ \\
\hline \multicolumn{2}{|c|}{ Minimum } & $5,44 \%$ & $1,52 \%$ & $0,00 \%$ & $0,00 \%$ & $0,00 \%$ & $0,00 \%$ \\
\hline \multicolumn{2}{|c|}{ Maximum } & $86,58 \%$ & $91,44 \%$ & $68,43 \%$ & $41,41 \%$ & $66,08 \%$ & $25,16 \%$ \\
\hline
\end{tabular}

According to Table 1, the differences varied for individual resources: e.g. we can see an 80 percentagepoint difference between the lowest and highest values of oil, a nearly 90 percentage point difference in gas, only 40 percentage point difference in case of nuclear energy and merely 25 percentage point difference in renewable energy resources. The standard deviations reveal similar results. In order to provide equal role for each sources during the cluster analysis, we used standardized values. During standardization the average ratio became " 0 " and 1 standard deviation became the basic unit of measurement. In other words, +1 means that in a certain country the ratio of a given type of energy resource is exactly 1 standard deviation larger than the average.
The clusters were created by hierarchic clustering, by using the Ward method. Within the individual steps, this method combines the existing clusters so that the inner heterogeneity of the new clusters would grow minimally.

The survey resulted in a 7 cluster model. The characteristics of this model can be viewed in Table 2 .

According to Table 2 we can see that each cluster contains one resource which is used in a considerably greater rate than in the other clusters. The only exception is cluster 2 which contains the most average values. Furthermore, we may state that in cluster 5, 6 and 7 the dominant portion of energy (in some cases 90\%) derives from 2-3 resources as follows: in cluster 5 primarily fossil oil and secondarily natural gas (together $88,5 \%$ ); in cluster 6 primarily natural gas and secondarily fossil oil (together 93,8\%); and finally in cluster 7 primarily coal, secondarily oil (together $84,6 \%$ ) complemented by natural gas (these three together already make up to $93,8 \%$ ). In the rest of the clusters the total consumption divides among several resources. Table 3 contains the place of the various states within the clusters.

\section{Connections among the Use of Various Resources}

We have examined if any connection among the percentages of the use of various resources exist. We have predicted, and the test had certainly proved it that if an economy leans on oil on a large scale, it uses nuclear energy in a lesser percentage; if a country leans on natural gas on a large scale, it uses

Table 2 The Characteristics of Clusters (by the authors, 2017)

\begin{tabular}{|c|c|c|c|c|c|c|c|}
\hline \multicolumn{2}{|c|}{ Ward Method } & \multirow{2}{*}{$\begin{array}{c}\text { fossil oil } \\
37,2 \%\end{array}$} & \multirow{2}{*}{$\begin{array}{c}\text { natural gas } \\
19,4 \%\end{array}$} & \multirow{2}{*}{$\begin{array}{c}\text { coal } \\
11,3 \%\end{array}$} & \multirow{2}{*}{$\begin{array}{c}\text { nuclear energy } \\
2,2 \%\end{array}$} & \multirow{2}{*}{$\begin{array}{c}\text { hydro power } \\
26,9 \%\end{array}$} & \multirow{2}{*}{$\begin{array}{c}\text { renewable energy } \\
2,8 \%\end{array}$} \\
\hline & Mean & & & & & & \\
\hline Cluster 1 & Std. Deviation & $8,4 \%$ & $8,7 \%$ & $11,6 \%$ & $5,4 \%$ & $12,4 \%$ & $3,3 \%$ \\
\hline \multirow{2}{*}{ Cluster 2} & Mean & $41,0 \%$ & $22,7 \%$ & $24,3 \%$ & $4,3 \%$ & $4,4 \%$ & $3,5 \%$ \\
\hline & Std. Deviation & $8,3 \%$ & $9,9 \%$ & $9,5 \%$ & $5,8 \%$ & $4,7 \%$ & $2,4 \%$ \\
\hline \multirow{2}{*}{ Cluster 3} & Mean & $24,3 \%$ & $15,5 \%$ & $21,5 \%$ & $23,6 \%$ & $9,6 \%$ & $5,5 \%$ \\
\hline & Std. Deviation & $7,5 \%$ & $9,7 \%$ & $15,1 \%$ & $8,4 \%$ & $10,8 \%$ & $4,5 \%$ \\
\hline \multirow{2}{*}{ Cluster 4} & Mean & $42,5 \%$ & $23,8 \%$ & $13,5 \%$ & $3,5 \%$ & $3,2 \%$ & $13,3 \%$ \\
\hline & Std. Deviation & $5,5 \%$ & $7,9 \%$ & $5,3 \%$ & $4,4 \%$ & $3,2 \%$ & $5,5 \%$ \\
\hline \multirow{2}{*}{ Cluster 5} & Mean & $59,3 \%$ & $29,2 \%$ & $5,5 \%$ & $0,2 \%$ & $4,2 \%$ & $1,6 \%$ \\
\hline & Std. Deviation & $13,3 \%$ & $15,9 \%$ & $7,7 \%$ & $0,5 \%$ & $7,5 \%$ & $2,0 \%$ \\
\hline \multirow{2}{*}{ Cluster 6} & Mean & $25,4 \%$ & $68,4 \%$ & $2,4 \%$ & $0,8 \%$ & $2,8 \%$ & $0,2 \%$ \\
\hline & Std. Deviation & $10,8 \%$ & $14,2 \%$ & $3,7 \%$ & $1,9 \%$ & $3,9 \%$ & $0,3 \%$ \\
\hline \multirow{2}{*}{ Cluster 7} & Mean & $24,2 \%$ & $9,2 \%$ & $60,4 \%$ & $0,9 \%$ & $3,3 \%$ & $2,0 \%$ \\
\hline & Std. Deviation & $3,6 \%$ & $5,4 \%$ & $6,0 \%$ & $0,9 \%$ & $3,4 \%$ & $1,8 \%$ \\
\hline \multirow{2}{*}{ Total } & Mean & $37,9 \%$ & $29,9 \%$ & $16,1 \%$ & $4,2 \%$ & $8,5 \%$ & $3,5 \%$ \\
\hline & Std. Deviation & $14,9 \%$ & $21,8 \%$ & $17,0 \%$ & $8,0 \%$ & $11,5 \%$ & $4,6 \%$ \\
\hline
\end{tabular}


Table 3 The place of countries (by the authors, 2017)

\begin{tabular}{|c|c|c|c|c|c|c|}
\hline $\begin{array}{l}\text { 1. Cluster } \\
\text { (hydropower) }\end{array}$ & $\begin{array}{l}\text { 2. Cluster } \\
\text { (average) }\end{array}$ & $\begin{array}{l}\text { 3. Cluster } \\
\text { (nuclear energy) }\end{array}$ & $\begin{array}{l}\text { 4. Cluster } \\
\text { (renewable } \\
\text { energy) }\end{array}$ & $\begin{array}{l}\text { 5. Cluster (fossil } \\
\text { oil) }\end{array}$ & $\begin{array}{l}\text { 6. Cluster (natural } \\
\text { gas) }\end{array}$ & 7. Cluster (coal) \\
\hline Austria & Australia & Bulgaria & Denmark & $\begin{array}{l}\text { China Hong Kong } \\
\text { SAR }\end{array}$ & Algeria & China \\
\hline Brazil & Belgium & Czech Republic & Germany & Ecuador & Argentina & India \\
\hline Canada & Chile & Finland & Ireland & Egypt & Azerbaijan & Kazakhstan \\
\hline Colombia & Greece & France & Italy & Kuwait & Bangladesh & Poland \\
\hline New Zealand & Hungary & Slovakia & Portugal & Lithuania & Belarus & South Africa \\
\hline Norway & Indonesia & Sweden & Spain & Mexico & Iran & \\
\hline Other Africa & Israel & Ukraine & United Kingdom & Netherlands & Pakistan & \\
\hline Other Asia Pacific & Japan & & & Other Middle East & Qatar & \\
\hline $\begin{array}{l}\text { Other Europe \& } \\
\text { Eurasia }\end{array}$ & Malaysia & & & $\begin{array}{l}\text { Other S. \& Cent. } \\
\text { America }\end{array}$ & Russian Federation & \\
\hline Peru & Philippines & & & Saudi Arabia & Trinidad \& Tobago & \\
\hline Switzerland & Romania & & & Singapore & Turkmenistan & \\
\hline Venezuela & South Korea & & & Thailand & $\begin{array}{l}\text { United Arab } \\
\text { Emirates }\end{array}$ & \\
\hline \multirow[t]{3}{*}{ Vietnam } & Taiwan & & & & Uzbekistan & \\
\hline & Turkey & & & & & \\
\hline & US & & & & & \\
\hline
\end{tabular}

coal, hydropower and other renewable energy sources on a lesser percentage. However, countries that use more coal, other renewable energy resources (not hydropower) as well as nuclear energy are more likely to be used. The usage of other renewables correlates positively with the use of nuclear energy and hydropower. Generally the correlations tend to be weaker than average.

The results of our study reflect the aspirations of the countries. China which belongs to the „coal” cluster, aims to decrease its excessive „coal-addiction”. Therefore, during the last two decades the renewable energy sector of China became a number one factor within the entire renewable energy investment sector and capacity. In the single year of 2015, China established a larger capacity of wind power and solar energy than any other country (REN21, 2016).

Figure 3Solar Cell Capacity in 2015 (Gigawatt)(REN21, 2016)

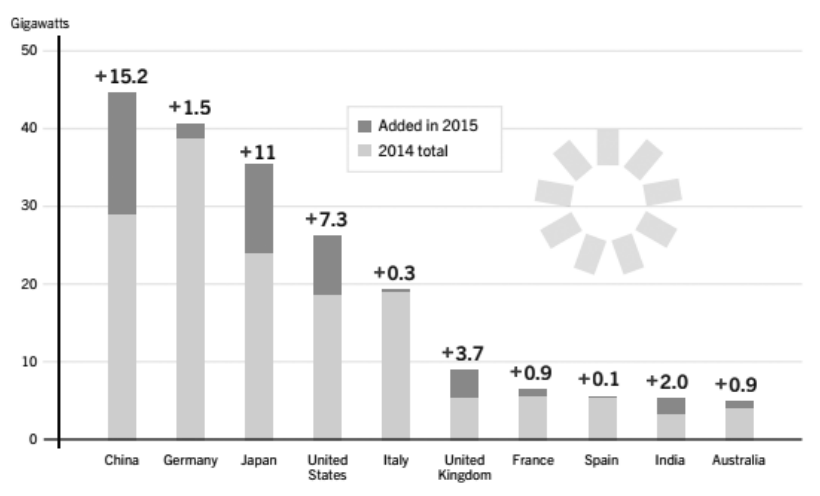

Figure 4 Wind Power 2015 (Gigawatt)(REN21, 2016)

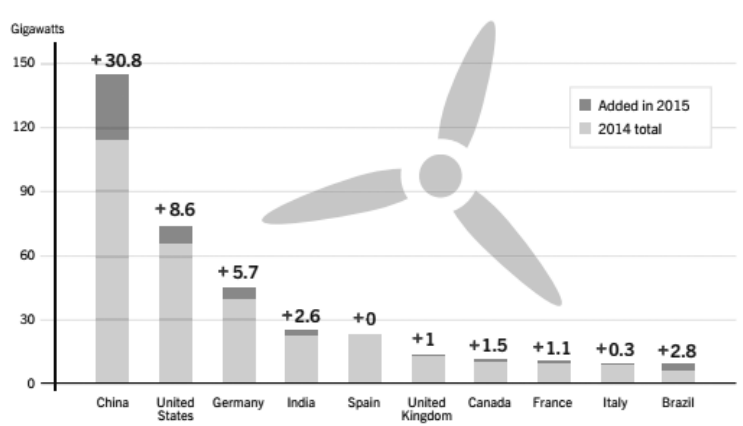

India, another significant member of the „coal” cluster, also obliged to produce renewable energies. By 2022, India plans to establish the capacity of $175 \mathrm{GW}$ renewable energy, out of this 100GW solar energy, 75GWhydropower, wind power, biomass and other renewable energy resources produced by small works. By 2030, India also plans to increase the rate of non-fossil energy carriers up to $40 \%$ within the electric energy sector. The country simultaneously aims to liquidate the shortage of energy and to increase renewable energy. Furthermore, the government of India attempts to secure a non-stop, 24 hour electricity supply for each household by 2022 and provide electric power for every single village by 2019 . In accordance with the announced government program, a significant increase can be experienced in the renewable energy sector of India within the last two years. (Krishnaswamy, n.d.)

South Africa, which also belongs to the „coal” cluster, is the only African country which possesses a nuclear power plant. Originally South Africa meant to establish 6 to 8 nuclear 
power plants, but constructions came to a halt in 2016, and the execution was postponed. In 2007 the country began the construction of two new coal-fed power plants, which were supposed to start operating in 2011, however, the constructions have not been completed even by the beginning of 2016. South Africa introduced the Renewable Energy Independent Power Producer's Procurement Programme (REIPPPP) in 2011. This program aimed to add $3,75 \mathrm{GW}$ capacity to the network. The program proved to be very successful, even exceeded the original goal mainly by the purchase procedures. (JOUBERT, n.d.)

\section{The Composition of Clusters According to HDI}

The theoretical base of creating HDI originates from the Nobel-Prize winner Amartya Sen. Sen differentiates among the possibilities which may be defined as the resources available to humans, and the accomplishments achieved through these resources. This distinction is based on the theory that individuals -playing an active role shaping their lives - judge the accessible realizations in a different manorin accordance with their various preferences.Therefore, if we only evaluate life quality through the actual living conditions than we partially compare different preferences. Consequently, the theories of resource aspects, which include the conception of human development, measure quality of life based on the scale of available resources for individuals, which are sufficient for reaching the highly valued living conditions (BERGER- SCHMITT, 2000).

One of the biggest advantages of the index is that - due to its complex nature - it means an alternative that displays reality in a more complete manner to one-dimensional approaches. However, it's value - thanks to the small data requrement - when compared to indicator systems - its value can be calculated for multiple countries, making comparisons possible, and its simple construction makes it easy to use (STREETEN, 1994; SAGARNAJAM, 1998; ZAPF, 2000).

During our research we employed HDI categories as follows:

- HDI Category 4 equals extremely high HDI

- HDI Category 3 equals high HDI

- HDI Category 2 equals average HDI

- HDI Category 1 equals low HDI

None of the examined countries belonged to the low HDI group. The analysis did not include the combined categories (e.g. Other Africa, Other Europe \& Eurasia and Taiwan).

Figure 5 The composition of clusters according to HDI (by the authors, 2017)

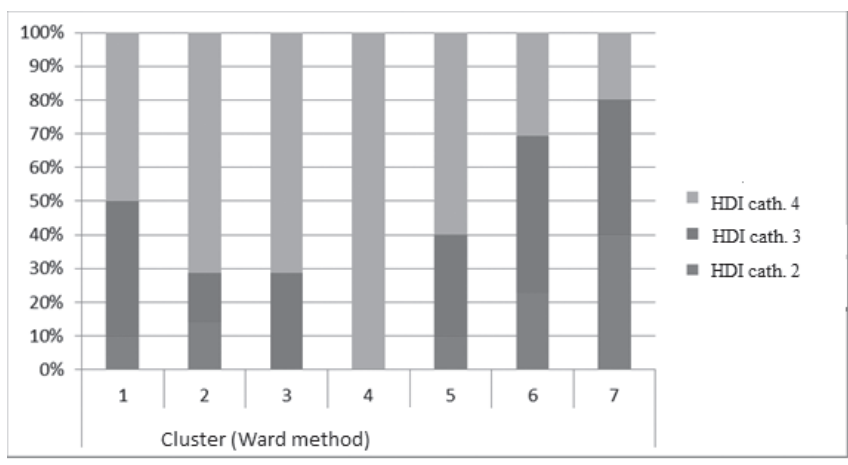

Figure 5 reveals that the countries of cluster 4, using renewable energies on a larger scale, obtain an extremely high HDI, and in cluster 2 and 3 we find a larger proportion of countries with extremely high HDI. The proportion of countries characterized by average HDI was the highest in cluster 6 (relying on natural gas) and 7 (relying on coal).

\section{Connections among the Countries' Competitiveness}

There is no commonly accepted formula to measure competitiveness. The Global Competitiveness Index (GCI), created by the World Economic Forum, examines competitiveness along 12 aspects. It consists of three sub indexes: the sub index of basic requirements (this includes institutions, infrastructure, the macroeconomic environment, healthcare and primary education), the sub index of increasing effectivity (this includes the parameters characterizing the higher education and trainings, the market as well as labormarket effectivity, the development of the financial market, the availability of technology and the size of market), as well as the sub index of innovation and refinement (which helps to analyse the refinement of innovation and business procedures). GCI results from the collective calculation of these twelve aspects (THE GLOBAL COMPETITIVENESS REPORT, 2016)

The countries included into the analyses were ranked between 1 and 132 based on their competitiveness. During the examination we used GCI categories as follows:

- Countries ranked 1-44 establish GCI category group 1, or high GCI

- Countries ranked 45-88 establish GCI category group 2, or average GCI

- Countries ranked 89-132 establish GCI category group 3, or low GCI

Figure 6 The composition of clusters based on GCI (by the authors, 2017)

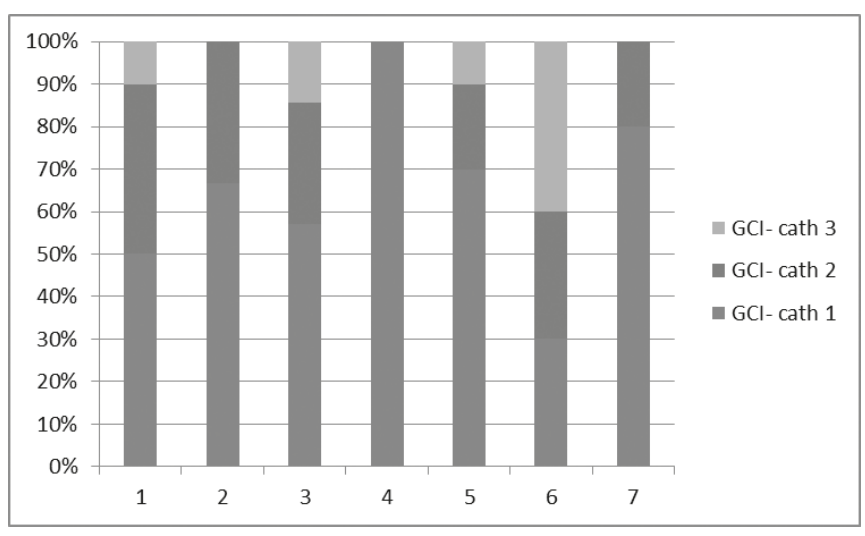

Figure 6 demonstrates that the countries of cluster 4 (which use renewable energy resources on a larger scale) are the best in competitiveness as well as the countries of cluster 7, or „coal" cluster and cluster 2 or „average" cluster which are also found at the top of the competitiveness ranking. Based on the analysis the countries with the lowest competitiveness are found in cluster 6 or "natural gas” cluster. 


\section{Cluster 4 (Countries using renewable energy resources on a larger scale)}

Each country of cluster 4 (which uses renewable energy sources on a larger scale) is a member of the European Union. In case of cluster 4 in which the countries use renewable energy resources other than hydropower on the largest scale, the average and median of HDI, GNI and competitiveness index is the highest.

As Figure 7 demonstrates, the transformation of energy production continues rapidly in Europe.

\section{Figure 7 Facilities producing net electric energy in the European Union 1995-2015 (MW) \\ (THE EUROPEAN WIND ENERGY ASSOCIATION)}

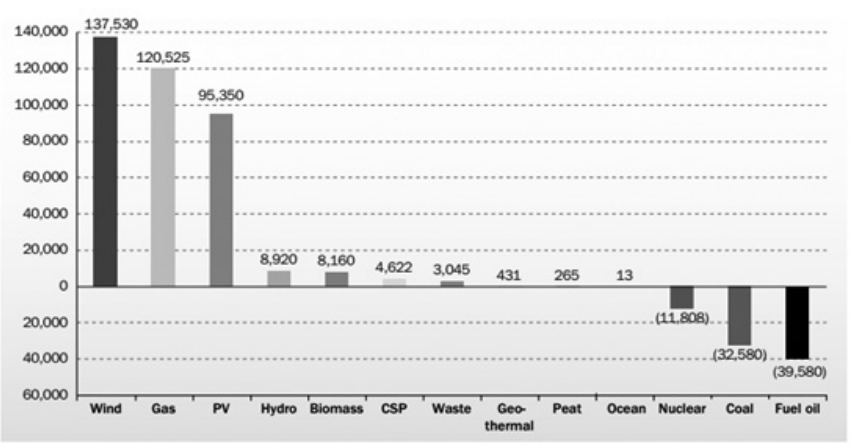

In the past twenty years, in EU countries the expansion of capacity basically regarded three technologies, the wind power plants, the gas-powered electricity production and the solar cell systems. In countries of cluster 4 the use of alternative energy sources became more and more a priority, e.g. in Portugal $48 \%$ of electric energy production originated from renewable energy in 2015, out of which a significant portion, $22 \%$ was consisted of wind power. This ratio is only higher in Denmark, where wind power plants provide $42 \%$ of electric energy production. At the same time, wind power makes up only $20 \%$ in Spain, $13 \%$ in Germany and $11 \%$ in the United Kingdom (ZERO). In Portugal between May 7 and 11, 2016 the electric power needs were covered solely by renewable resources for 107 hours. This meant close to $90 \%$ of the total usage. A similar event happened in Germany on May 8, 2016. Due to the favourable weather conditions (windy and sunny weather) the electricity production deriving from renewable energy resources increased outstandingly - these plants produced $87 \%$ of the daily supplies. The changing of the structure of the energy sector will be a long procedure. Because of the large amount and long term funds the energy system can only transform slowly. Germany could have become a front runner in the production of renewable energy because, due to the oil crises, it significantly increased the budgetary spending for research and development (R\&D) already during the seventies in order to promote the exploitation of renewable energy sources. The necessity of these investments was boosted by the catastropheofChernobyl. Thanks to the several decadeslong, steady R\&D budgetary support, a wide research development network was formed by scientists, small and medium size businesses and large firms. This network focuses on renewable energy from basic research to technological production.

\section{CONCLUSION}

One of the most important issues of our time is the secure energy supply of economies as well as the moderation of the carbon dioxide emission and harms deriving from it.

The growth of global energy need continues in our present times. Therefore, it is crucial what type of energy resources we use, how effectively we are able to use energy, since these factors are closely connected to the amount of carbon dioxide emission. The issues of energy efficiency and renewable energies cannot be separated from each other. The diversification of the energy sector is one possible way to answer these questions, and therefore the politicians in charge must consider them and must build their strategies based upon them. The energy sector of countries in certain clusters does not reveal any characteristics of diversification. In case of the countries in cluster 5, which use primarily fossil oil and secondarily natural gas, these sources together, provide $88,5 \%$ of the applied energy, while in cluster 6 where the countries use primarily natural gas and secondarily fossil oil the two sources make up 93,8\% of the combined usage. According to the predictions, the oil and gas supplies will not drain during the following decades because continuously new deposits are discovered and new exploitation technologies are introduced. The most difficult question is how to determine the price of oil and gas since these are largelyaffected by political event. (PÁPAY, 2015)

According to this study, the importance of the renewable energy sources other than hydropower is larger in economies where the competitiveness index, HDI and the GNI is higher. In other words the first world economies use renewable energies on a larger scale. The economies of the „coal” cluster are also committed to improve the usage of renewal energy. China became world leader in increasing the capacity of wind power and solar energy in 2015. The energy produced by the renewable power plants becomes ever cheaper since technologies improve continuously. Investments pay off more due to the lower and lower price of energy. In addition to this, due to the governmental support more and more renewable power plants are constructed. Europe stands by climate protection efforts and supports the production and use of renewable energy. Hopefully, as a result, Hungary will also benefit from the lower energy prices.

\section{REFERENCES}

AZ ÉGHAJLATVÁLTOZÁSRÓL SZÓLÓ PÁRIZSI MEGÁLLAPODÁS. (2016). Az Európai Unió Tanácsa: http://www.consilium.europa.eu/hu/policies/climate-change/timeline/ Approached 14. 05.2017

BERGER-SCHMITT, R.-H.-H. N. (2000). Conceptual framework and structure of a European system of social indicators. Mannheim: EUreporting Working Paper, No. 9.

BP. (2016). BP Energy Outlook: http://www.bp.com/en/global/corporate/energy-economics/energy-outlook/energy-outlook-downloads.html Approached 03.05. 2017 
GLOBAL ENERGY STATISTICAL YEARBOOK (2016) https:// yearbook.enerdata.net/\#CO2-emissions-data-from-uel-combustion.html Approached 03.05. 2017

GROSSMAN, G. M., KRUEGER, A. B., (1995) The Quarterly Journal of Economics, 110, 2, pp.353-77.

JEVONS, S. W. (1866): The Coal Question. An Inquiry Concerning the Progress of the Nation and the

Probable Exhaustion of Our Coal-Mines. Macmillan, London.

JOUBERT, L. (n.d.). A NÉMET ENERGIAÁTMENET KÖNYVE https://book.energytransition.org/hu/node/78 Approached 27.05. 2017

KEMP , R.-SCHOT, J.-HOOGMA , R. (1998): Regime Shifts to Sustainability Through Processes of Niche Formation: The Approach of Strategic Niche Management. Technology Analysis \& Strategic Management, Vol. 10. Iss 2. pp.175-195.

KERR , R.,- SERVICE, R. (2005). What Can Replace Cheap Oil—and When. Science, 309 (5731), 101.

KUZNETS, S. (1955), The American Economic Review, XLV,1, pp.1-28.

THE GLOBAL COMPETITIVENESS REPORT (2016). http:// reports.weforum.org/global-competitiveness-index/ Approached 14.05. 2017.

KRISHNASWAMY, S. (n.d.). A NÉMET ENERGIAÁTMENET KÖNYVE: https://book.energytransition.org/hu/node/78 Approached 27.05. 2017.

REN21. (n.d.). RENEWABLES 2016 GLOBAL STATUS REPORT: http://www.ren21.net/wp-content/uploads/2016/06/ GSR_2016_Full_Report.pdf Approached 21.05. 2017.

PÁPAY , J. (2015). Konvencionális és nem konvencionális kőolajés földgázkitermelő eljárások.

Magyar Tudomány, 176. évfolyam 2015/11. pp. 1285-1294.

SAGAR, AMBUJ D.-ADIL NAJAM (1998). The Human Development Index: a critical review. Ecological Economics: (25), pp. 249-264.

STREETEN, P. (1994). Human development: means and ends. The American Economic Review: Papers and Proceedings, Vol. 84. Iss 2, pp. 232-237.

SZLÁVIK, J. (2013). Fenntartható gazdálkodás. Budapest: COMPLEX KIADÓ KFT.

UNITED NATIONS PARIS AGREEMENT ON CLIMATE CHANGE (2015). Paris Agreement: http://unfccc.int/paris_agreement/items/9485.php Approached14.05. 2017.

UNITED NATIONS FRAMEWORK CONVENTION ON CLIMATE CHANGE. (n.d.). Kyoto Protocol: http://unfecc.int/kyoto_ protocol/items/2830.php Approached14.05. 2017.

ZAPF, W.( 2000) Social reporting in the 1970s and in the 1990s. Social Indicators Research, Vol. 51. Iss 1 pp.1-15.

ZERO. (n.d.). http://zero.ong/consumo-de-eletricidade-em-portugal-foi-assegurado-durante-mais-de-4-dias-seguidos-por-fontesrenovaveis/ Approached 14.05. 2017.

YORK, R. (2006): Ecological Paradoxes: William Stanley Jevons and the Paperless Office. Human

Ecology Review, Vol. 13. Iss 2. pp.143-147. 
